\title{
Bio-Based Polyols from Seed Oils for Water-Blown Rigid Polyurethane Foam Preparation
}

\author{
Paweena Ekkaphan, ${ }^{1}$ Sarintip Sooksai, ${ }^{2}$ Nuanphun Chantarasiri, ${ }^{3}$ and Amorn Petsom ${ }^{3}$ \\ ${ }^{1}$ Program of Petrochemistry, Faculty of Science, Chulalongkorn University, Bangkok 10330, Thailand \\ ${ }^{2}$ Institute of Biotechnology and Genetic Engineering, Chulalongkorn University, Bangkok 10330, Thailand \\ ${ }^{3}$ Department of Chemistry, Faculty of Science, Chulalongkorn University, Bangkok 10330, Thailand \\ Correspondence should be addressed to Amorn Petsom; amorn.p@chula.ac.th
}

Received 2 June 2016; Revised 17 August 2016; Accepted 28 August 2016

Academic Editor: Luc Averous

Copyright (C) 2016 Paweena Ekkaphan et al. This is an open access article distributed under the Creative Commons Attribution License, which permits unrestricted use, distribution, and reproduction in any medium, provided the original work is properly cited.

\begin{abstract}
The preparation of water-blown rigid polyurethane (RPUR) foams using bio-based polyols from sesame seed oil and pumpkin seed oil has been reported. Polyols synthesis involved two steps, namely, hydroxylation and alcoholysis reaction. FTIR, NMR, and ESI-MS were used to monitor the process of the synthesized polyols and their physicochemical properties were determined. The resulting polyols have $\mathrm{OH}$ number in the range of $340-351 \mathrm{mg} \mathrm{KOH} / \mathrm{g}$. RPUR foams blown with water were produced from the reaction of biopolyols with commercial polymeric methylene diphenyl diisocyanate (PMDI). The proper PUR formulations can be manipulated to produce the desired material applications. These seed oil-based RPUR foams exhibited relatively high compressive strength $(237.7-240.2 \mathrm{kPa})$ with the density in the range of $40-45 \mathrm{~kg} / \mathrm{m}^{3}$. Additionally, the cell foam morphology investigated by scanning electron microscope indicated that their cellular structure presented mostly polygonal closed cells. The experimental results demonstrate that these bio-based polyols can be used as an alternative starting material for RPUR production.
\end{abstract}

\section{Introduction}

Polyurethane (PUR) foams are produced based on the basis of exothermic addition polymerization between two or more isocyanate groups and polyhydroxy compounds (polyols) to form urethane linkage. This reaction will occur under room temperature by adding a small amount of suitable catalysts such as tertiary amine and tin compounds. The cell structure of foam is formed by stabilizing gas bubble generation in polymer matrix. Hence, the blowing agent and silicone surfactant are essentially required [1]. Within this requirement, water is used as a blowing agent for many researches and industrial processes and carbon dioxide gas evolves out via the highly exothermic reaction between water and isocyanates [2]. Based on the simple basic chemistry and processing of PUR foams, the world of PUR foam production is recently increasing with the versatile applications especially in automotive industry, footwear, furnishing, packaging, insulation, construction, and so forth. The wide variety of PUR foam grades can be manufactured by modifying and controlling the nature of the main starting components (isocyanates and polyols) and the properties of end used products [1].

Commercially, both starting materials for PUR production are mainly derived from petrochemical precursors which are exhausted rapidly and are not in consonance with environmental friendly requirements. In seeking for an alternative renewable resource, plant oils are available in abundance with cost effectiveness and have the potential to replace the petroleum based PUR. Vegetable oils are reactive triglyceride molecules containing a variation of fatty acids proportion which can be modified by chemical reaction to obtain polyalcohol compounds. Recently, the ongoing use of plant oils for polyols synthesis has been intensively investigated by many researchers. Although seed oils from agricultural harvests including castor oil, soybean oil, linseed oil, canola oil, rapeseed oil, and palm oil are widely used as the raw materials for polyols production, new alternative feedstock has been progressively discovered and developed [3-7]. In this study, the utilization of highly polyunsaturated 
seed oils, namely, sesame seed oil and pumpkin seed oil, was investigated.

From the literature reviews, there are several methods to synthesize bio-based polyols from vegetable oils [8-11]. The conventional chemical methodology for the functionality of unsaturated moieties to produce $\mathrm{OH}$ groups is the most operational such as in situ epoxidation-hydroxylation at the double bonds with percarboxylic acids to obtain mostly secondary $\mathrm{OH}$ groups with low hydroxyl number $[12,13]$, the hydroformylation with syngas $\left(\mathrm{H}_{2} / \mathrm{CO}\right)$ in the presence of transition metal catalysts following the hydrogenation of resulting aldehydes to form primary $\mathrm{OH}$ groups [14, 15], and the ozonolysis of triglycerides forming aldehydes and subsequent reduction to primary $\mathrm{OH}$ groups $[16,17]$. In addition to the well-known alcoholysis of vegetable oils with polyfunctional alcohols in the presence of acidic or basic catalysts which has been reported, the resulting products are the mixture of fatty acid alkyl esters [18-22]. Among the variety of chemical modifications of seed oils, the in situ epoxidation-hydroxylation and alcoholysis reaction is used for the preparation of bio-based polyols in this work, due to its industrial applicability and low cost.

As mentioned before, the objective of this work is to synthesize bio-based polyols from sesame seed oil and pumpkin seed oil using a two-step reaction. Firstly, hydroxylation reaction of seed oil occurred under excess performic acid condition and then the alcoholysis of hydroxylated seed oils with triethanolamine in the presence of lithium hydroxide as a catalyst was carried out. The second purpose is the preparation of water-blown RPUR foams using these bio-based polyols reacting with the polymeric methylene diphenyl diisocyanate (PMDI) in the presence of $N, N$-dimethylcyclohexylamine (DMCHA) as catalyst and silicone surfactant. Furthermore, the mechanical and thermal properties of optimized biobased foams were determined.

\section{Materials and Methods}

2.1. Materials. Sesame seed oil and pumpkin seed oil were provided by the Institute of Biotechnology and Genetic Engineering, Chulalongkorn University. Their characteristics and fatty acid profile are illustrated in Table 1 . Hydrogen peroxide (30 wt\%) from Merck, formic acid (98wt\%) from Fisher Scientific, triethanolamine (85wt\%) from Ajax Finechem, and lithium hydroxide ( $99 \mathrm{wt} \%$ ) from Fluka were used for polyols preparation.

For the preparation of water-blown RPUR foams, the isocyanate Suprasec ${ }^{\circledR} 5005$ (polymeric methylene diphenyl diisocyanate $(\mathrm{PMDI})$; NCO content $=31.0 \mathrm{wt} \%$; average functionality $=2.7$ ), the commercial polyether polyol Raypol $4218(\mathrm{OH}$ number $=438 \mathrm{mg} \mathrm{KOH} / \mathrm{g})$, the polyether dimethyl siloxane surfactant TEGOSTAB ${ }^{\circledR}$ B8460, and the foaming catalyst DMCHA (N,N-dimethylcyclohexylamine) were supplied from Huntsman (Thailand) Co., Ltd. and IRPC Public Co., Ltd.

\subsection{Synthesis of Seed Oil-Based Polyols}

2.2.1. Hydroxylation of Seed Oils. A portion of $30 \mathrm{wt} \%$ of hydrogen peroxide $(0.27 \mathrm{~mol}, 27.60 \mathrm{~mL})$ and $98 \mathrm{wt} \%$ of formic
TABLE 1: Characteristics and fatty acid composition of sesame seed oil and pumpkin seed oil.

\begin{tabular}{lcc}
\hline & Sesame seed oil & Pumpkin seed oil \\
\hline Color (naked eyes) & Light brown & Dark green \\
Viscosity (at $\left.25^{\circ} \mathrm{C}, \mathrm{cps}\right)$ & $136 \pm 3$ & $160 \pm 6$ \\
Acid value (mg KOH/g) & $7.23 \pm 0.18$ & $2.13 \pm 0.14$ \\
Water content (wt\%) & 0.08 & 0.09 \\
\hline Fatty acid (FA) profile (wt\%) & & \\
Palmitic acid (C16:0) & 11.40 & 13.04 \\
Stearic acid (C18:0) & 4.30 & 4.60 \\
Oleic acid (C18:1) & 37.00 & 34.82 \\
Linoleic acid (C18:2) & 47.30 & 47.55 \\
Total unsaturated FAs & 84.30 & 82.37 \\
\hline
\end{tabular}

acid $(0.54 \mathrm{~mol}, 20.80 \mathrm{~mL})$ were mixed in a three-neck round bottom flask equipped with a stirrer, reflux condenser, and a thermometer. The mixture was heated to $40^{\circ} \mathrm{C}$ with constant stirring. Then the vegetable oil $(0.18 \mathrm{~mol}, 50.00 \mathrm{~g})$ was added dropwise and the temperature was kept at $40-50^{\circ} \mathrm{C}$ for 3 hours. After that, the reaction mixture was allowed to cool to room temperature. The liquid separated clearly into two layers. The bottom layer was removed, and the hydroxylated oil in the upper layer was recovered and distilled under vacuum to eliminate the remaining water and acid. The hydroxylated sesame seed oil was light pale yellow viscous liquid, whereas the hydroxylated pumpkin seed oil was dark green liquid.

2.2.2. Alcoholysis of Hydroxylated Seed Oils. The hydroxylated vegetable oil ( $1 \mathrm{~mol}, 50.00 \mathrm{~g}$ ), $85 \mathrm{wt} \%$ of triethanolamine $(3 \mathrm{~mol}, 30.17 \mathrm{~g})$, and lithium hydroxide $(0.2 \mathrm{wt} \%$ of total weight, $0.16 \mathrm{~g}$ ) were mixed together in a flask with mechanical stirrer and thermometer. The reaction mixture was constantly stirred as the temperature was raised to $150^{\circ} \mathrm{C}$ in 0.5 hours. The reaction was continued at this temperature for 2.5 hours. The obtained polyols were dark pale yellow liquid with high viscosity. The resulting polyols were used without further purification.

\subsection{Polyols Characterization}

2.3.1. Hydroxyl Number. $\mathrm{OH}$ numbers of seed oil-based polyols were determined according to ASTM D4274-11, test method D-reflux phthalation [23].

2.3.2. Acid Number. The acid number of polyols was evaluated following ASTM D4662-08 [24].

2.3.3. Water Content. The water content of polyols is defined as the water concentration $(\mathrm{mg} / \mathrm{kg}$ or percentage) contained in the synthesized polyols which could be determined using a Metrohm $831 \mathrm{KF}$ coulometer with $703 \mathrm{Ti}$ stand. The coulometric Karl Fischer titration procedure was performed according to ASTM D6304-07, procedure C-water evaporator accessory [25]. 
2.3.4. Viscosity Measurement. The dynamic viscosity of synthesized polyols was determined using a digital VR 3000 MYR viscometer at $25 \pm 0.1^{\circ} \mathrm{C}$.

\subsubsection{Fourier Transform Infrared Spectroscopy. FTIR spectra} of starting materials and PUR foam samples were collected using a Thermo Scientific Nicolet 6700 FTIR spectrometer equipped with a Smart iTR diamond attenuated total reflectance (ATR) accessory operated at $4 \mathrm{~cm}^{-1}$ spectral resolution over the wavenumber range of $4000-650 \mathrm{~cm}^{-1}$.

2.3.6. Nuclear Magnetic Resonance Spectroscopy. ${ }^{1} \mathrm{H}$ NMR and ${ }^{13} \mathrm{C}$ NMR spectra were recorded in deuterated chloroform $\left(\mathrm{CDCl}_{3}\right)$ on a Bruker Avance 400 nuclear magnetic resonance spectrometer which operated at $400 \mathrm{MHz}$ for ${ }^{1} \mathrm{H}$ and $100 \mathrm{MHz}$ for ${ }^{13} \mathrm{C}$ nuclei. The chemical shifts $(\delta)$ are reported in parts per million (ppm) relative to the residual $\mathrm{CHCl}_{3}$ signal (7.26 ppm for ${ }^{1} \mathrm{H} \mathrm{NMR}$ and $77.0 \mathrm{ppm}$ for ${ }^{13} \mathrm{C}$ NMR).

2.3.7. Electrospray Ionization-Mass Spectrometry. The components of synthesized polyols were characterized using electrospray ionization-mass spectrometry (ESI-MS). Mass spectrometry was carried out in positive ionization model on an amaZon SL Ion Trap Mass Spectrometers (Bruker Daltonics, Germany) equipped with a standard ESI source and HyStar 3.1 (Bruker Daltonics, Germany) control software. The sample was diluted in acetonitrile and then injected by direct infusion with a syringe pump at flow rate of $3.0 \mu \mathrm{L} / \mathrm{min}$ using nitrogen both as nebulizer and as drying gas. Ion source voltages consisted of $140 \mathrm{~V}$ of capillary exit and scanned mass range was $70-1000 \mathrm{~m} / z$. In order to determine the free triethanolamine, the sample was diluted with acetonitrile containing $0.1 \%$ of formic acid and performed, following the same condition of qualitative analysis.

2.4. Rigid Polyurethane Foam Preparation. RPUR foams from seed oil-based polyols and commercial polyol were prepared by one-shot method [1]. Polyols, surfactant, catalyst, and blowing agent were premixed in a $700 \mathrm{~mL}$ paper cup with mechanical stirrer at $2000 \mathrm{rpm}$ until they became homogeneous. Subsequently, a calculated amount of PMDI was added rapidly into the resulting mixture and was stirred continuously for $15 \mathrm{~s}$ at the same speed. The foam was allowed to rise and set freely at ambient condition. During foam generation, the foaming profile including (a) cream time, (b) gel time, (c) tack-free time, and (d) rise time [26] was recorded by a digital stop watch. After free-rise foaming had been completed, the foams were cured at room temperature for 48 hours before their physical and mechanical properties test. All sample tests were prepared in triplicate.

The proportions of starting materials were calculated, which were 100 parts by weight (pbw) of polyols, shown in Table 2. The final RPUR foams have been produced with desired density at $40-45 \mathrm{~kg} / \mathrm{m}^{3}$. The resulting foam samples were further investigated for their mechanical and thermal properties.
TABLE 2: Water-blown RPUR foams formulation.

\begin{tabular}{lc}
\hline Ingredients & Amount $\left(\mathrm{pbw}^{\mathrm{a}}\right)$ \\
\hline Polyols & 100 \\
$\quad$ Seed oil-based polyols & 1.0 \\
Polyether polyols (Raypol $\left.{ }^{\circledR} 4218\right)$ & 3.0 \\
Catalyst (DMCHA) & 2.5 \\
Blowing agent (distilled water) & NCO index ${ }^{\mathrm{b}} 175$ \\
Surfactant (TEGOSTAB & ${ }^{\circledR}$ B8460) \\
PMDI (Suprasec ${ }^{\circledR}$ 5005) & \\
${ }^{\mathrm{a}}$ The amounts of ingredients were calculated to be parts per $100 \mathrm{wt} \%$ of \\
polyols. \\
${ }^{b}$ NCO index refers to the excess amount of PMDI used over the theoretical \\
equivalent amount which is required, expressed in percentage terms [1].
\end{tabular}

\subsection{Foam Properties Measurement}

2.5.1. Apparent Density. The density of all foams was measured according to ASTM D1622-08 [27]. The foam samples were cut into cubes with dimension of $30 \times 30 \times 30 \mathrm{~mm}$. The exact dimensions were measured using a vernier caliper and accurately weighed to determine their densities $\left(\mathrm{kg} / \mathrm{m}^{3}\right)$. The average of five measurements was calculated.

2.5.2. Compression Testing. Compressive tests of foams parallel and perpendicular to the foam rise direction were performed using a Lloyd LRX universal testing machine. The dimension of the foam specimen was $30 \times 30 \times 30 \mathrm{~mm}$ (width $\times$ length $\times$ thickness). The rate of crosshead movement was fixed at $2.54 \mathrm{~mm} / \mathrm{min}$ and the preload cell used was $0.1000 \mathrm{~N}$. The compressive strength at $10 \%$ deformation of its original thickness was calculated and the average value of three specimens was reported.

2.5.3. Morphology. The cellular structure of foams was observed using Hitachi S-4800 scanning electron microscope (SEM). The small portions of foams were cut and sliced carefully with sharp blade and stuck onto aluminum stubs. Then the samples were sputter-coated with gold before scanning under an accelerating voltage of $20 \mathrm{kV}$.

2.5.4. Thermal Properties. The percentage weight loss and thermal degradation characteristics of RPUR foam samples were examined by thermogravimetric analysis (TGA) using Mettler Toledo TGA/SDTA $851^{\mathrm{e}}$. The initial amount of test samples was approximately $2-20 \mathrm{mg}$. The samples were heated from ambient temperature to $800^{\circ} \mathrm{C}$ at a heating rate of $10^{\circ} \mathrm{C} / \mathrm{min}$ under nitrogen gas atmosphere $[19,28]$.

The room temperature thermal conductivity was performed using the Hot Disk Thermal Constant Analyzer TPS2500 (Hot Disk AB) with $50 \times 50 \times 20 \mathrm{~mm}$ (width $\times$ length $\times$ thickness) of sample size. Disk type was Kapton Insulation (sensor number C7577, radius $=2.001 \mathrm{~mm}$ ). Three measurements were made for each study and the average was reported. 
TABLE 3: Physicochemical properties of modified seed oils.

\begin{tabular}{|c|c|c|c|}
\hline Types & Properties & Sesame seed oil & Pumpkin seed oil \\
\hline \multirow{4}{*}{ Unmodified } & Color (visual) & Light blown & Dark green \\
\hline & Viscosity (at $\left.25^{\circ} \mathrm{C}, \mathrm{cP}\right)$ & $136 \pm 3$ & $160 \pm 6$ \\
\hline & Acid value (mg KOH/g) & $7.23 \pm 0.18$ & $2.13 \pm 0.14$ \\
\hline & Water content $(w t \%)$ & 0.08 & 0.09 \\
\hline \multirow{5}{*}{ Hydroxylation } & Color (visual) & Brown & Dark green \\
\hline & Viscosity (at $25^{\circ} \mathrm{C}, \mathrm{cP}$ ) & $7302 \pm 19$ & $6722 \pm 19$ \\
\hline & $\mathrm{OH}$ number (mg KOH/g) & $85.64 \pm 0.91$ & $84.25 \pm 1.04$ \\
\hline & Acid value (mg KOH/g) & $16.30 \pm 0.18$ & $10.27 \pm 0.16$ \\
\hline & Water content $(\mathrm{wt} \%)$ & 0.38 & 0.80 \\
\hline \multirow{5}{*}{ Alcoholysis } & Color (visual) & Brown & Dark green \\
\hline & Viscosity (at $\left.25^{\circ} \mathrm{C}, \mathrm{cP}\right)$ & $11278 \pm 29$ & $9862 \pm 47$ \\
\hline & $\mathrm{OH}$ number (mg KOH/g) & $351.03 \pm 3.84$ & $340.24 \pm 6.80$ \\
\hline & Acid value (mg KOH/g) & $10.29 \pm 0.21$ & $5.37 \pm 0.19$ \\
\hline & Water content (wt $\%)$ & 0.53 & 0.83 \\
\hline
\end{tabular}

\section{Results and Discussion}

3.1. Synthesis and Characterization of Seed Oil-Based Polyols. The biopolyols from sesame seed oil (SSO) and pumpkin seed oil (PO) can be synthesized by two steps, which comprise hydroxylation and alcoholysis reactions. The composition of fatty acid in their nature has high double bonds content as shown in Table 1 . They can be simply modified at unsaturated units to introduce multiple $\mathrm{OH}$ groups by first hydroxylation reaction with commonly used oxidizing agents such as peroxy acids. For this study, peroxyformic acids were generated by the reactions of formic acid with hydrogen peroxide to react at double bonds position of fatty acid chains. The occurring epoxide intermediates could be open ringed subsequently under strong acidic condition to form $\mathrm{OH}$ groups $[10,12]$.

Table 3 shows the characteristics of modified seed oils. Based on the unsaturated fatty acid composition sesame seed oil-based and pumpkin seed oil-based polyols had $\mathrm{OH}$ value as 351 and $340 \mathrm{mg} \mathrm{KOH} / \mathrm{g}$, respectively, which could be used as a typical requirement for RPUR foam preparation. The viscosity of synthesized products was increased after the first and second modification since the increase of $\mathrm{OH}$ groups generates the strong intermolecular and intramolecular interaction. The viscosity of PO polyol is lower than that of SSO polyol. Moreover, the trend of acid value of modified seed oils was rising due to the synthetic process which occurred under acidic condition.

3.2. FTIR Analysis. The ATR-IR spectroscopy was used for qualitative identification of the chemical reaction of the polyols formation by the assignments of the major signals of unmodified seed oils and modified seed oils. Since IR spectra of all neat, hydroxylated, and alcoholized seed oils had similar characteristics, the ATR-IR data of sesame seed oil were only presented in Figure 1.

For the ATR-IR spectrum of virgin seed oil (Figure 1(a)), the main peaks of triglyceride functional groups could be
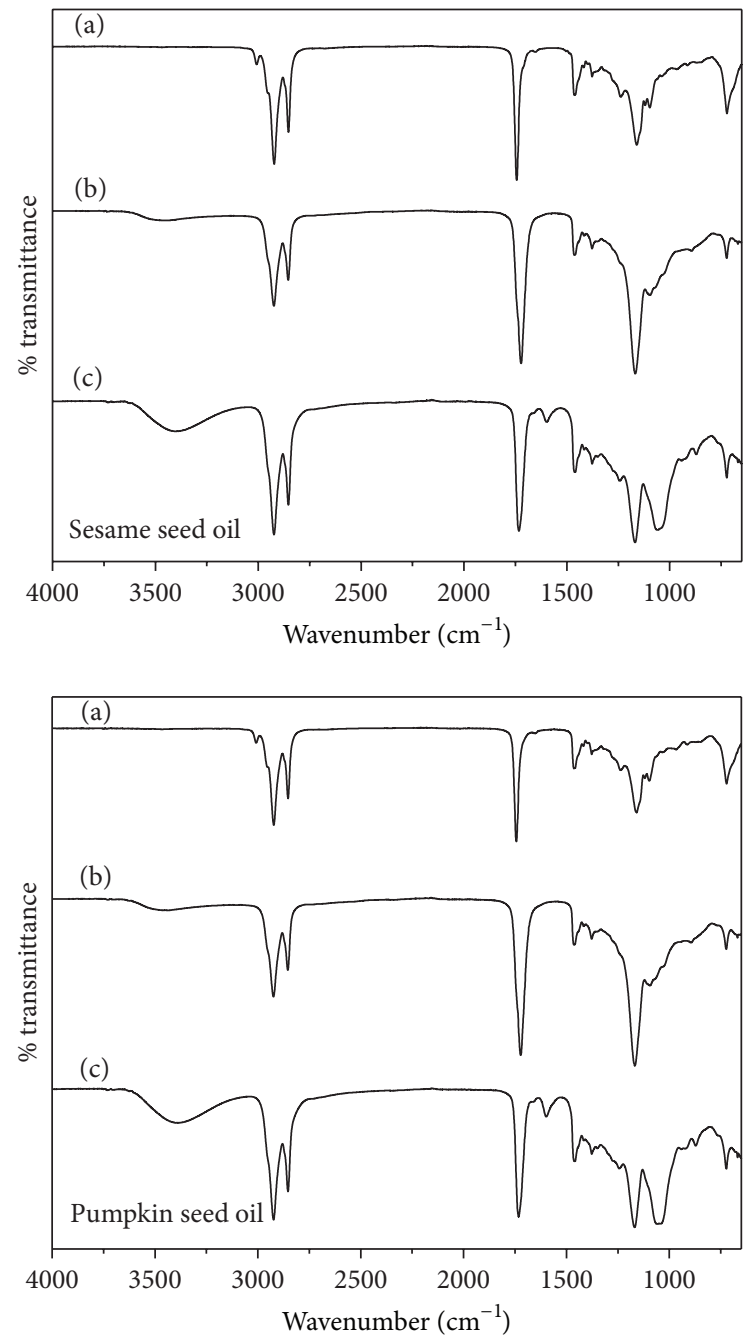

FIGURE 1: ATR-IR spectra of unmodified and modified seed oils: (a) virgin seed oil, (b) hydroxylated seed oil, and (c) alcoholized hydroxylated sesame seed oil. 


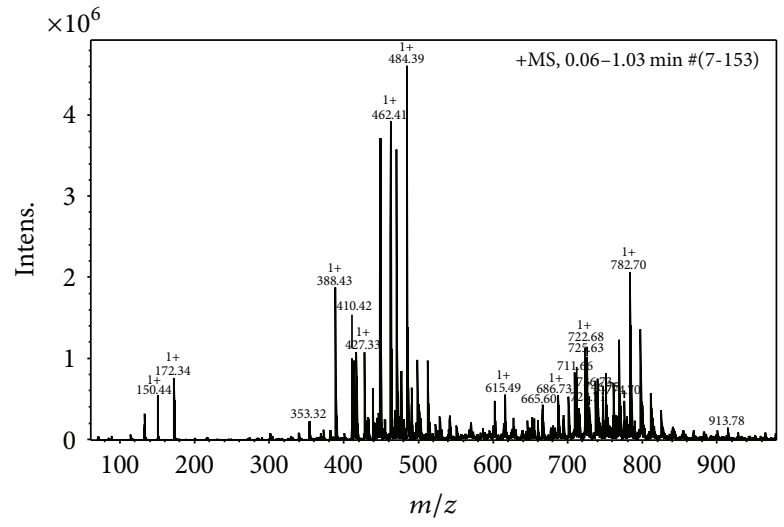

(a)

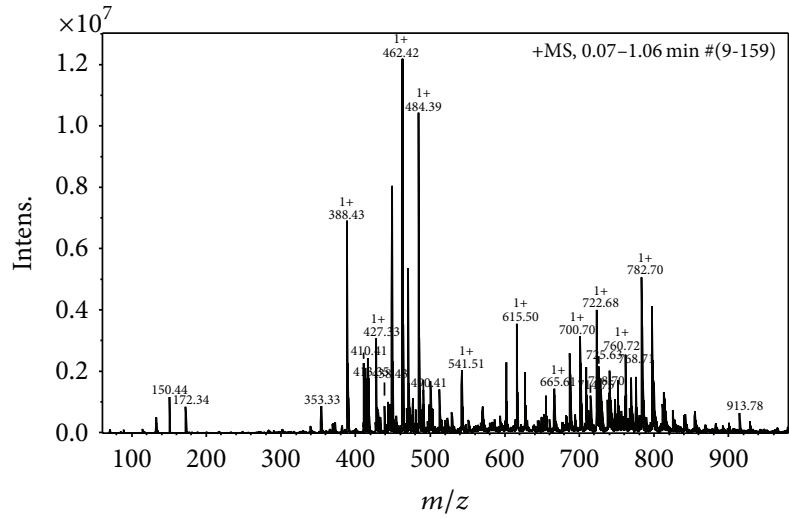

(b)

FIGURE 2: The positive ion ESI-MS spectra of synthesized seed oil-based polyols scanned at 70-1000 $\mathrm{m} / z$ : (a) sesame seed oil-based polyol and (b) pumpkin seed oil-based polyol, respectively.

clearly observed. The peaks at 2925,2853 , and $1459 \mathrm{~cm}^{-1}$ were attributed to the asymmetric and symmetric $\mathrm{C}-\mathrm{H}$ stretching and $\mathrm{C}-\mathrm{H}$ bending vibration of $-\mathrm{CH}_{2}-$ groups, respectively. The strong signal at $1740 \mathrm{~cm}^{-1}$ was assigned to $\mathrm{C}=\mathrm{O}$ stretch of triglyceride ester groups. The weak absorption band (a shoulder) at $3014 \mathrm{~cm}^{-1}$ corresponded to $\mathrm{C}-\mathrm{H}$ stretching of aliphatic $\mathrm{C}=\mathrm{C}-\mathrm{H}$ group, whereas the very small peak at $1649 \mathrm{~cm}^{-1}$ was attributed to $\mathrm{C}=\mathrm{C}$ stretching vibration in $c$ is conformation. Moreover, the $\mathrm{C}-\mathrm{O}$ stretch of ester groups could be observed at $1164 \mathrm{~cm}^{-1}$. After modification, the most important difference was the presence of a broadband around $3300-3500 \mathrm{~cm}^{-1}$, indicating an increase in hydroxyl groups by chemical reaction in agreement with higher $\mathrm{OH}$ numbers especially after alcoholysis. For hydroxylated oil, the double bonds absorption at 3014 and $1649 \mathrm{~cm}^{-1}$ disappeared, while the hydroxyl band was presented as shown in Figure $1(\mathrm{~b}$ and c). It was indicated that an unsaturated position in fatty acid chains was almost completely functionalized. Additionally, the characteristic peak of secondary hydroxyl group was shown in hydroxylated oil at around $1099 \mathrm{~cm}^{-1}$ region. Furthermore, the ester carbonyl peak of modified seed oil appeared broader and shifted from $1740 \mathrm{~cm}^{-1}$ to 1720 $1730 \mathrm{~cm}^{-1}$, probably due to the esters and acids generated during the chemical process. When the alcoholysis reaction with triethanolamine was carried out, the obtained polyols were the mixture of various esters of triglycerides. In addition, the peak at signal $1596 \mathrm{~cm}^{-1}$ corresponded to the amides of fatty acids which occurred by aminolysis side reaction of triglyceride with triethanolamine $[12,21]$. Besides, the band at $1057 \mathrm{~cm}^{-1}$ appeared in alcoholized seed oil arising from C$\mathrm{O}$ stretching vibration of triethanolamine.

However, there was clearly no research that studied and reported the amount of free triethanolamine present in the obtained polyols. Therefore, the remaining triethanolamine in the synthesized polyols was firstly confirmed and determined in this study using electrospray ionization-mass spectrometry. Furthermore, free triethanolamine decreased the foaming times and increased the compressive strength of RPUR foams prepared from the vegetable oil-based polyols.

3.3. NMR Analysis. The chemical structures of the obtained biopolyols were characterized using ${ }^{1} \mathrm{H}$ NMR and ${ }^{13} \mathrm{C}$ NMR analysis.

From NMR data of sesame seed oil-based polyol and pumpkin seed oil-based polyol (Figures S1 and S2 in Supplementary Material available online at http://dx.doi.org/10.1155/ 2016/4909857), the presence of low signals at chemical shift $(\delta)$ of $5.40 \mathrm{ppm}$ in ${ }^{1} \mathrm{H}$ NMR and at $\delta=125-135 \mathrm{ppm}$ in ${ }^{13} \mathrm{C}$ NMR was assigned to the remaining unsaturated fatty acid $(\mathrm{CH}=\mathrm{CH})$ in polyols. Moreover, the small signals above $\delta$ $=8.40 \mathrm{ppm}$ in ${ }^{1} \mathrm{H}$ NMR and at $\delta=170-172 \mathrm{ppm}$ in ${ }^{13} \mathrm{C}$ NMR corresponded to the acid groups. These NMR data gave the characteristics of the main functional groups presenting in these biopolyols agreeing with those identified by FTIR analysis.

\subsection{ESI-MS Analysis}

3.4.1. Qualitative Analysis of Synthesized Polyols. The synthesized seed oil-based polyols for rigid polyurethane foam preparation were formerly used without any purification and the foaming process and foam properties could be affected by the various components presented in these biopolyols. Therefore, the obtained polyols were characterized to identify the individual structural components using electrospray ionization-mass spectrometer (ESI-MS) in positive ionization mode. Figure 2 represents the full scanned mass spectra of SSO polyol and PO polyol, respectively. The observed mass profiles of the major peaks are summarized in Table 4.

From ESI-MS data of the obtained polyols, the disappearance of glycerol peaks at $[\mathrm{M}+\mathrm{Na}]^{+}, m / z 115$ was observed. It indicated that the biopolyols synthesized from the alcoholysis of hydroxylated seed oils and triethanolamine had variety of species, which mainly includes monoester and diester containing a variation of hydroxylated fatty acid chains. 
TABLE 4: The main structural components in synthesized seed oil-based polyols identified by ESI-MS in positive ionization mode.

\begin{tabular}{|c|c|c|c|c|c|c|}
\hline \multirow{3}{*}{ Structure } & \multirow{2}{*}{\multicolumn{2}{|c|}{ Calculated mass }} & \multicolumn{4}{|c|}{ Observed mass detected in seed oil-based polyols } \\
\hline & & & \multicolumn{2}{|c|}{ Sesame seed oil } & \multicolumn{2}{|c|}{ Pumpkin seed oil } \\
\hline & {$[\mathrm{M}+\mathrm{H}]^{+}$} & {$[\mathrm{M}+\mathrm{Na}]^{+}$} & {$[\mathrm{M}+\mathrm{H}]^{+}$} & {$[\mathrm{M}+\mathrm{Na}]^{+}$} & {$[\mathrm{M}+\mathrm{H}]^{+}$} & {$[\mathrm{M}+\mathrm{Na}]^{+}$} \\
\hline \multicolumn{7}{|l|}{ Esters with triethanolamine } \\
\hline Monoester-C $(16: 0)^{*}$ & 388.34 & 410.32 & 388.43 & 410.42 & 388.43 & 410.41 \\
\hline Monoester-C(18:0) & 416.37 & 438.36 & 416.46 & 438.44 & 416.46 & 438.43 \\
\hline Monoester-C(18:0)-diol & 448.36 & 470.35 & 448.45 & 470.42 & 448.44 & 470.41 \\
\hline Monoester- $\mathrm{C}(18: 0)$-tetraol $-\mathrm{H}_{2} \mathrm{O}$ & 462.34 & 484.32 & 462.41 & 484.39 & 462.42 & 484.39 \\
\hline Diester-C $(16: 16: 0)^{* *}$ & 626.57 & 648.55 & 626.69 & - & 626.69 & - \\
\hline Diester-C(16:18:0) & 654.60 & 676.58 & 654.70 & - & 654.71 & 676.69 \\
\hline Diester-C(16:18:0)-diol & 686.59 & 708.57 & 686.73 & 708.71 & 686.72 & 708.70 \\
\hline Diester-C(16:18:0)-tetraol $-\mathrm{H}_{2} \mathrm{O}$ & 700.57 & 722.55 & 700.70 & 722.68 & 700.70 & 722.68 \\
\hline Diester-C(18:18:0)-diol & 714.62 & 736.61 & 714.75 & 736.73 & 714.75 & 736.71 \\
\hline Diester-C(18:18:0)-tetraol & 746.61 & 768.60 & 746.75 & 768.72 & 746.74 & 768.71 \\
\hline Diester-C(18:18:0)-tetraol $-\mathrm{H}_{2} \mathrm{O}$ & 728.60 & 750.59 & 728.71 & 750.71 & 728.70 & 750.71 \\
\hline Diester-C(18:18:0)-hexaol & 778.60 & 800.59 & 778.72 & - & - & - \\
\hline Diester-C(18:18:0)-hexaol - $\mathrm{H}_{2} \mathrm{O}$ & 760.59 & 782.57 & 760.72 & 782.70 & 760.72 & 782.70 \\
\hline Diester-C(18:18:0)-octaol $-2 \mathrm{H}_{2} \mathrm{O}$ & 774.57 & 796.55 & 774.70 & 796.69 & 774.70 & 796.67 \\
\hline \multicolumn{7}{|l|}{ Esters with triglyceride } \\
\hline Monoglyceride-C(16:0) ${ }^{*}$ & 331.28 & 353.27 & - & 353.32 & - & 353.32 \\
\hline Monoglyceride-C(18:0) & 359.32 & 381.30 & - & - & - & 381.35 \\
\hline Monoglyceride-C(18:0)-diol & 391.31 & 413.29 & - & 413.36 & - & 413.35 \\
\hline Monoglyceride- $\mathrm{C}(18: 0)$-tetraol $-\mathrm{H}_{2} \mathrm{O}$ & 405.28 & 427.27 & - & 427.33 & - & 427.33 \\
\hline Diglyceride-C $(16: 16: 0)^{* *}$ & 569.51 & 591.50 & 569.55 & - & 569.53 & - \\
\hline Diglyceride- $\mathrm{C}(16: 18: 0)-\mathrm{H}_{2} \mathrm{O}$ & 579.53 & 601.52 & - & 601.53 & - & 601.53 \\
\hline Diglyceride-C(16:18:2) & 593.51 & 615.50 & - & 615.49 & - & 615.50 \\
\hline Diglyceride-C(16:18:0)-diol & 629.53 & 651.52 & - & 651.54 & - & - \\
\hline
\end{tabular}

${ }^{*} \mathrm{C}(m: n) ; m$, number of carbon atoms in fatty acid chain; $n$, number of double bonds remaining in fatty acid chain.

${ }^{* *} \mathrm{C}(x: y: z) ; x$, number of carbon atoms in 1st fatty acid chain; $y$, number of carbon atoms in 2 nd fatty acid chain; and $z$, number of double bonds remaining in fatty acid chain.

Additionally, the esters of triglyceride and the unreacted triethanolamine were detected in all the polyol systems.

\subsubsection{Quantitative Analysis of Free Triethanolamine Presented} in Polyols. In PUR foam system, isocyanates could react with every active hydrogen compounds such as polyols, water, and amines. From ESI-MS data, the presence of free triethanolamine was significantly detected. Triethanolamine in synthesized polyols might affect the properties of RPUR foams. It has been reported that triethanolamine was used as a cocatalyst with tin compound in the foaming process [29]. Moreover, at high concentration, it was used as cross-link agent that provided the RPUR foams with high compressive strength without concerning the other properties [29]. Therefore, the quantitative analysis of triethanolamine remaining in SSO polyol and PO polyol was studied and calculated from total mass spectra of triethanolamine peaks at $[\mathrm{M}+\mathrm{H}]^{+}, m / z$ $150,[\mathrm{M}+\mathrm{Na}]^{+}, m / z 172$, and $[\mathrm{M}+\mathrm{K}]^{+}, m / z$ 188. It was found that the amounts of unreacted triethanolamine in SSO polyol and PO polyol were $1.95 \pm 0.19 w \mathrm{wt} \%$ of polyol and $0.52 \pm$ $0.01 \mathrm{wt} \%$ of polyol, respectively. That significantly affected the reaction times and foam properties especially foam density as shown in Table 5. It shows that foaming times of bio-based RPUR foams were shorter than those of commercial foam. The low amount of free triethanolamine presenting in these biopolyols (typically $0.5-5.0 \mathrm{wt} \%$ of polyols) acts as a foaming catalyst accelerating the foaming time [30, 31]. In addition, it is known that polyurethane foams are highly complex systems. Practically, the specific formulation needs to be optimized in order to balance these reactions to obtain the desirable foam products [1]. The further study should evaluate and optimize the triethanolamine content used for synthesized polyols in the alcoholysis step, while the other parameters were kept constant.

3.5. Preparation and Properties of RPUR Foams. In this work, the low density RPUR foams were produced with the density in the range of $40-45 \mathrm{~kg} / \mathrm{m}^{3}$ with optimal formulation, shown in Table 2. From Table 5, although the foaming times of prepared seed oil-based RPUR foams were shorter than those of commercial foams, these characteristic times were acceptable for the production of foams by cup foaming method [27]. Furthermore, they promoted the low density bio-based foams. The foaming profile and density of biobased foams were decreased not only by the presence of 
TABLE 5: Physical properties of RPUR foams prepared from optimized formulations.

\begin{tabular}{|c|c|c|c|c|}
\hline \multirow{2}{*}{\multicolumn{2}{|c|}{ Property }} & \multicolumn{3}{|c|}{ PUR foam } \\
\hline & & Sesame seed oil & Pumpkin seed oil & Raypol ${ }^{\circledR} 4218$ \\
\hline \multirow{4}{*}{ Foaming time $(\mathrm{s})$} & Cream time & $23 \pm 2$ & $22 \pm 1$ & $32 \pm 1$ \\
\hline & Gel time & $37 \pm 1$ & $36 \pm 1$ & $44 \pm 1$ \\
\hline & Tack-free time & $188 \pm 4$ & $181 \pm 2$ & $242 \pm 3$ \\
\hline & Rise time & $156 \pm 4$ & $145 \pm 4$ & $186 \pm 3$ \\
\hline Density $\left(\mathrm{kg} / \mathrm{m}^{3}\right)$ & & $40.84 \pm 0.33$ & $40.78 \pm 0.56$ & $44.05 \pm 0.34$ \\
\hline \multirow{2}{*}{ Compressive strength $(\mathrm{kPa})$} & Parallel to foam rise direction & $240.2 \pm 17.5$ & $237.7 \pm 10.3$ & $303.1 \pm 26.8$ \\
\hline & Perpendicular to foam rise direction & $152.2 \pm 21.3$ & $152.3 \pm 23.1$ & $303.1 \pm 26.8$ \\
\hline \multicolumn{2}{|c|}{ Thermal conductivity $(\mathrm{W} / \mathrm{mK})$ at $25^{\circ} \mathrm{C}$} & $0.0342 \pm 0.0001$ & $0.0339 \pm 0.0001$ & $0.0368 \pm 0.0003$ \\
\hline
\end{tabular}

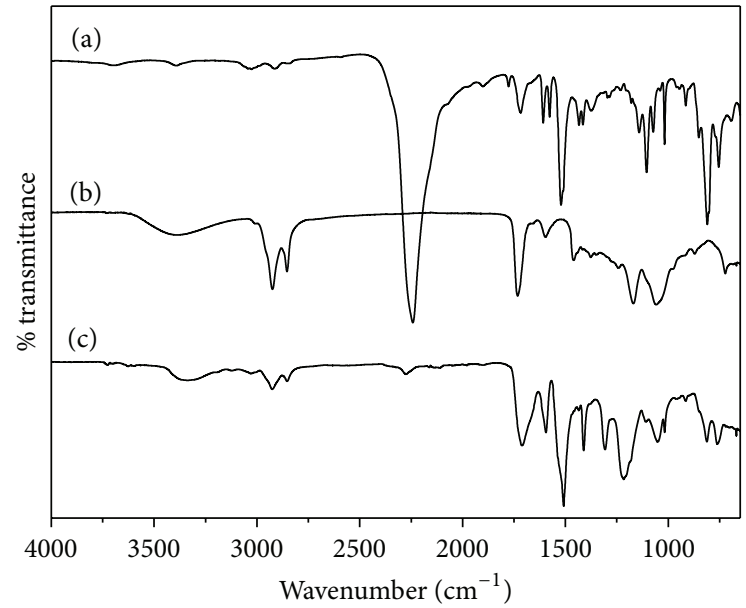

FIGURE 3: ATR-IR spectra of starting materials and PUR foam: (a) PMDI, (b) seed oil polyols, and (c) seed oil PUR foam.

triethanolamine but also by the nature of polyols. The synthesized polyols mainly composed of polyester with $\mathrm{OH}$ number $=340-351 \mathrm{mg} \mathrm{KOH} / \mathrm{g}$, while Raypol 4218 polyol was polyether polyol having $\mathrm{OH}$ number $=438 \mathrm{mg} \mathrm{KOH} / \mathrm{g}$. The shorter foaming time and lower density of seed oil-based foams resulted from the lower cross-link polymer occurring in foam system.

The ATR-IR spectra of main starting materials and resulting seed oil-based RPUR foams are shown in Figure 3. It was worth noting that a broad hydroxyl band at $3300-3500 \mathrm{~cm}^{-1}$ and a free carbonyl group vibration peak at $1733 \mathrm{~cm}^{-1}$ in polyols were decreased, while the presence of characteristics absorption peaks of urethane and urea linkages was observed in RPUR foam. The peaks at 3345 and $1709 \mathrm{~cm}^{-1}$ were attributed to $\mathrm{N}-\mathrm{H}$ stretching and $\mathrm{C}=\mathrm{O}$ stretching vibration, respectively, whereas the signals at 1505 and $1215 \mathrm{~cm}^{-1}$ were assigned according to $\mathrm{N}-\mathrm{H}$ bending and $\mathrm{C}-\mathrm{N}-\mathrm{H}$ asymmetric stretches of urethane and urea groups. Additionally, the characteristic bands at $2240 \mathrm{~cm}^{-1}$ region presented in RPUR foam corresponded to an unreacted $-\mathrm{N}=\mathrm{C}=\mathrm{O}$ group. Moreover, the isocyanurate network formation by additional trimerization of isocyanates could be observed as two peaks at 1594 and
$1412 \mathrm{~cm}^{-1}$, associating with $\mathrm{Ar}-\mathrm{H}$ and $\mathrm{C}-\mathrm{N}$ isocyanurate [20, 28].

3.6. Morphology of RPUR Foams. The SEM images of foam samples are shown in Figure 4. The structure of seed oil-based cell foams in the free-rise direction exhibited highly uniform and mostly closed cells. The rupture of cell membrane and some open cells might result from cutting samples. The foam cellular structure comprised dodecahedron-shaped cells (cell size of approximately $300-400 \mu \mathrm{m}$ ) with struts (cell edges) and thin cell window films [1]. In a converse direction, the foam cells were partially elongated probably resulting from mold shape under higher temperature and gas pressure present in core polymer matrix during foam expansion [12, $32,33]$.

3.7. Mechanical Properties of RPUR Foams. Table 5 shows some mechanical properties of the RPUR foams which were prepared following optimal formulation. All RPUR foams were produced at a density in the range of $40-45 \mathrm{~kg} / \mathrm{m}^{3}$ which gave satisfactory mechanical properties for thermal insulating applications. Typically, the compressive strength of RPUR foams with this density range is from 250 to $300 \mathrm{kPa}$ [29].

The compression stress-strain curves of all synthesized RPUR foams with loading both parallel and transverse directions to the foam rising were presented in Figure 5. Each curve shows three regions related to a deformation mechanism $[34,35]$. There was a relationship between the initial linear domain at low stress and the elasticity of the materials; this was due to cell window stretching because of trapped gas pressure and their slope is Young's modulus. After that, the long linear plateau region is observed at the stress value which does not change much. This collapsed plateau corresponds gradually to the collapsed cell by elastic buckling of cell walls or in brittle foams depending on the nature of solid polymer and cell morphology. The compressive strength is acquired from the stress at the yield point if it appears before $10 \%$ deformation or, in the absence of the yield point, from the stress at $10 \%$ deformation $[29,36]$. When the cell wall was almost completely collapsed and crushed, the stress level is increased rapidly through the solid polymer. This third domain can be referred to as densification. 

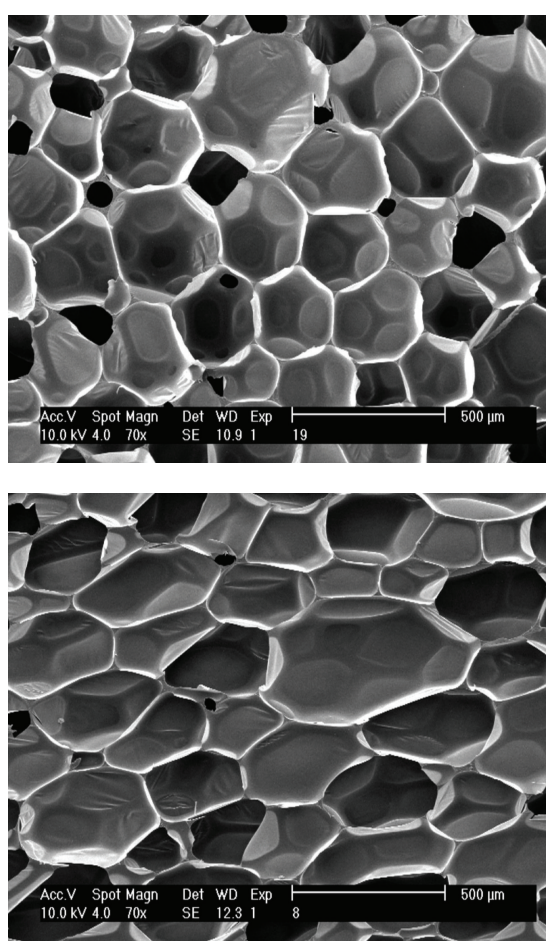

(a)
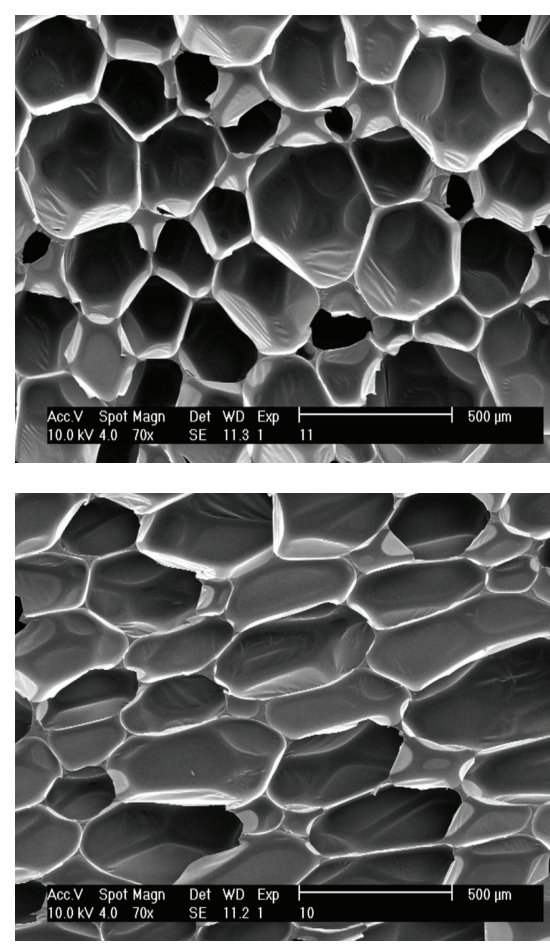

(b)
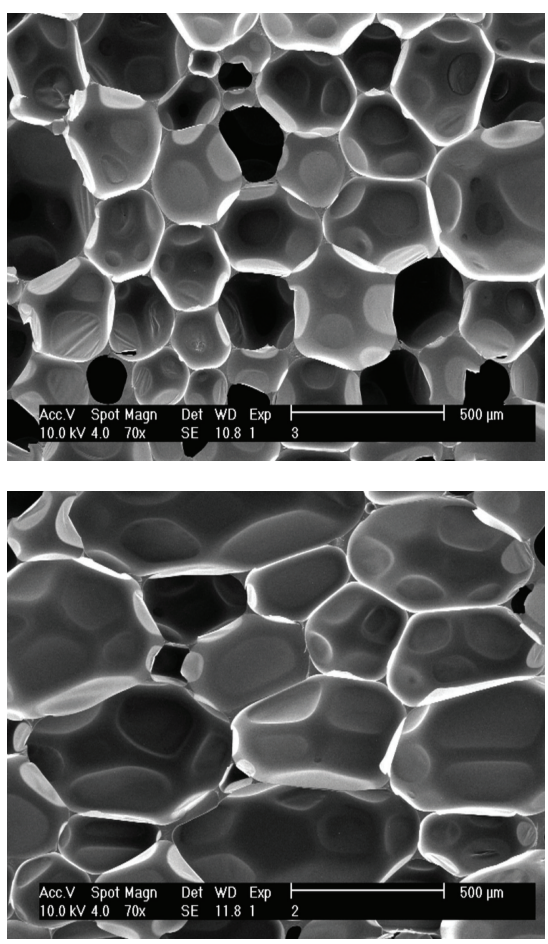

(c)

FIGURE 4: SEM micrographs of resulting PUR foams in top view (upper) and side view (lower) of mold (50x): (a) sesame seed oil-based, (b) pumpkin seed oil-based, and (c) Raypol ${ }^{\circledR} 4218$-based foams.

The compressive strength of RPUR foam samples in parallel to the foam rising was within the range of 237.7$240.2 \mathrm{kPa}$, whereas the compression in perpendicular direction was about $152 \mathrm{kPa}$. For low density RPUR foams, the compression strength would usually be dissimilar with the direction of the foam rise because of their anisotropy [2]. Raypol 4218 based foam showed higher compressive strength than seed oil-based foams because of its highest cross-link density. Although it was known that the strength properties of cellular materials do not only primarily depend on their density, this phenomenon was dependent on the basis of the polyols structure. The synthesized PUR foams had a variation of degree of cross-linking which leads to a difference in their mechanical properties [12, 28, 37]. When using polyester polyols from vegetable oils, the fatty acid chain would act as soft segment by plasticizing effects; therefore, the rigidity of the RPUR foams which were synthesized from these polyester polyols is less than that of commercial polyether polyols $[8,28,37]$.

As all RPUR foam samples displayed the anisotropy in compression, it was presumed that many cells were not perfectly spherical which was confirmed by SEM. From correlation data, it is supported that the mechanical properties of the cellular materials depend considerably on their densities and cell morphology $[1,2]$.

3.8. Thermal Properties of RPUR Foams. Thermal stability of seed oil-based RPUR foams and the commercial foams which had the density of $40-45 \mathrm{~kg} / \mathrm{m}^{3}$ was investigated by TGA performed in nitrogen atmosphere. TGA and their derivative (DTG) curves are presented in Figure 6. The DTG curves revealed two distinct degradation stages. The initial decomposition temperature at $5 \%$ weight loss of all biopolyolsbased RPUR foams was observed at approximately $258^{\circ} \mathrm{C}$ and the first decomposition stage $\left(T_{\max 1}\right)$ in the range of $300-330^{\circ} \mathrm{C}$ was associated to the degradation of thermally unstable urethane linkage. The second weight loss stage $\left(T_{\max 2}\right)$ occurred approximately at $425-470^{\circ} \mathrm{C}$, correlating to the decomposition of the polyols chains, which could be dependent on the polyols structures and different internal cross-linking in polymer networks [11, 12].

In addition, the room temperature thermal conductivity of synthesized RPUR foams was presented in Table 5. The thermal conductivity value of the prepared water-blown RPUR foams was in the range of $0.0339-0.0368 \mathrm{~W} / \mathrm{mK}$ which was higher than idealized RPUR foams $(0.020-0.030 \mathrm{~W} / \mathrm{mK})$ [2]. Generally, it is accepted that the total thermal conductivity of PUR foams depends on the heat transfer between gas and polymer solid phase. The thermal conductivity of closed cell RPUR foams is relatively low because of small solid contents in the foam materials about $3-10 \%$ of the total volume. Therefore, their insulation performance is mainly governed by the conduction of trapped gas types and foam density [1]. In this work, water-blown RPUR foams were prepared and cured at ambient temperature for 48 hours before characterization. When using water as a green blowing agent, carbon dioxide is generated to form the foam cells. Among conventional blowing agents such as HCFCs, HFCs, 

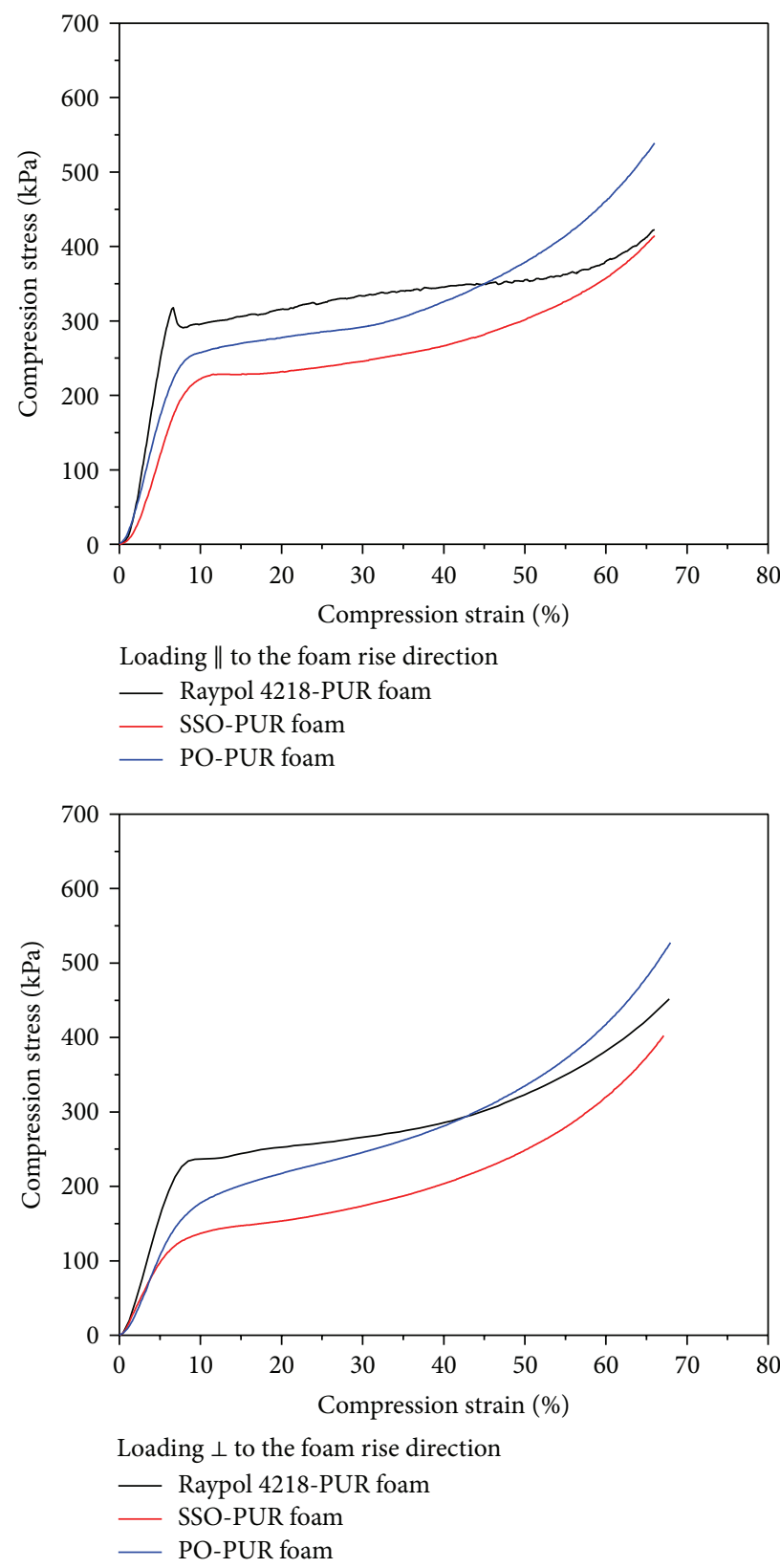

FIGURE 5: Compression strain versus stress curves of PUR foams parallel and perpendicular to the foam rise direction with foam density in the range of $40-45 \mathrm{~kg} / \mathrm{m}^{3}$.

and cyclopentane, $\mathrm{CO}_{2}$ has slightly higher gaseous thermal conductivity than those of other blowing agents (thermal conductivity of $\mathrm{CO}_{2} \sim 0.016 \mathrm{~W} / \mathrm{mK}$ at $25^{\circ} \mathrm{C}$ ) [2]. Although $\mathrm{CO}_{2}$ can diffuse out of foam within days, gases with large molecules can also take years to diffuse out of the same foam, and air can diffuse into the foam cells from several months to years. As a result, the thermal conductivity of full stabilization time of RPUR foams varied by several variations and it is difficult to measure under real environment [1]. Additionally, an increase in density of low density RPUR foams (30$50 \mathrm{~kg} / \mathrm{m}^{3}$ ) led to a decrease in the thermal conductivity of foams, caused by an increase of the closed cell contents per unit volume $[1,38]$. From the description above, the thermal conductivity of prepared RPUR foams using water as chemical blowing agent was moderately higher than those of commercial RPUR foams using other blowing agents such as HCFCs, HCFs, and pentane, primarily due to the captive gaseous blowing agent during foam process and after curing time $[1,2]$.

\section{Conclusion}

Bio-based polyols from an alternative resource including sesame and pumpkin seed oils were completely synthesized by simple hydroxylation following alcoholysis reaction. The resulting polyols exhibited $\mathrm{OH}$ number in the range of 

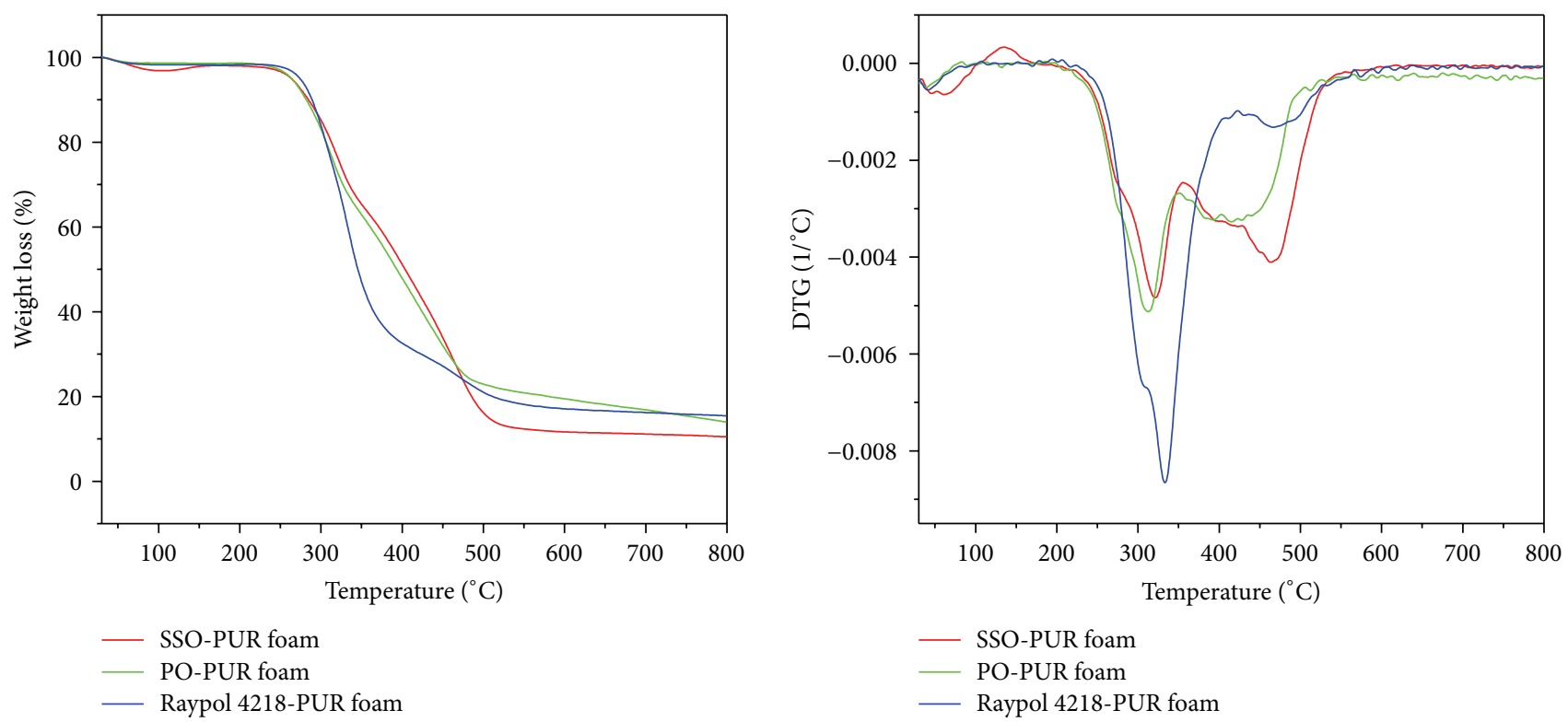

FIgURE 6: TGA and DTG curves of PUR foams at the heating rate of $10^{\circ} \mathrm{C} / \mathrm{min}$ in $\mathrm{N}_{2}$ atmosphere.

340-351 mg KOH/g, which is suitable for RPUR foam preparation, and relatively high viscosity (9862-11278 cps) comparable to commercial polyols. ATR-IR, NMR, and ESI-MS data were used to confirm the formation of polyols.

The water-blown RPUR foams from these biopolyols were successfully prepared by optimized formulation with the density in the range of $40-45 \mathrm{~kg} / \mathrm{m}^{3}$ and displayed the satisfactory mechanical and thermal performance. Additionally, the cellular structure of seed oil-based foams presented anisotropy in polygonal shaped cells. From the detailed experimental data, it was indicated that the obtained RPUR foams from seed oils not only exhibited behaviors slightly comparable to those of the commercial foams but also possessed the potential and favorable economics as a renewable resource for RPUR foam preparation.

\section{Competing Interests}

The authors declare that there are no competing interests regarding the publication of this paper.

\section{Acknowledgments}

The authors are grateful to 90th Anniversary Chulalongkorn University Scholarship, Chulalongkorn University, Bangkok, Thailand.

\section{References}

[1] S. T. Lee and N. S. Ramesh, Polymeric Foams: Mechanisms and Materials, CRC Press, Boca Raton, Fla, USA, 2004.

[2] G. Woods, The ICI Polyurethanes Book, John Wiley \& Sons, Amsterdam, The Netherlands, 2nd edition, 1990.
[3] G. Lligadas, J. C. Ronda, M. Galià, and V. Cádiz, "Renewable polymeric materials from vegetable oils: a perspective," Materials Today, vol. 16, no. 9, pp. 337-343, 2013.

[4] L. M. de Espinosa and M. A. R. Meier, "Plant oils: the perfect renewable resource for polymer science?!", European Polymer Journal, vol. 47, no. 5, pp. 837-852, 2011.

[5] S. Miao, P. Wang, Z. Su, and S. Zhang, "Vegetable-oil-based polymers as future polymeric biomaterials," Acta Biomaterialia, vol. 10, no. 4, pp. 1692-1704, 2014.

[6] C. Zhang, S. A. Madbouly, and M. R. Kessler, "Biobased polyurethanes prepared from different vegetable oils," ACS Applied Materials \& Interfaces, vol. 7, no. 2, pp. 1226-1233, 2015.

[7] X. Zhou, M. M. Sain, and K. Oksman, "Semi-rigid biopolyurethane foams based on palm-oil polyol and reinforced with cellulose nanocrystals," Composites Part A: Applied Science and Manufacturing, vol. 83, pp. 56-62, 2016.

[8] M. Desroches, M. Escouvois, R. Auvergne, S. Caillol, and B. Boutevin, "From vegetable oils to polyurethanes: synthetic routes to polyols and main industrial products," Polymer Reviews, vol. 52, no. 1, pp. 38-79, 2012.

[9] B. Nohra, L. Candy, J.-F. Blanco, C. Guerin, Y. Raoul, and Z. Mouloungui, "From petrochemical polyurethanes to biobased polyhydroxyurethanes," Macromolecules, vol. 46, no. 10, pp. 3771-3792, 2013.

[10] Y. Li, X. Luo, and S. Hu, Bio-Based Polyols and Polyurethanes, Springer, 2015.

[11] S. Bandyopadhyay-Ghosh, S. B. Ghosh, and M. Sain, "Synthesis of soy-polyol by two step continuous route and development of soy-based polyurethane foam," Journal of Polymers and the Environment, vol. 18, no. 3, pp. 437-442, 2010.

[12] V. B. Veronese, R. K. Menger, M. M. D. C. Forte, and C. L. Petzhold, "Rigid polyurethane foam based on modified vegetable oil," Journal of Applied Polymer Science, vol. 120, no. 1, pp. 530-537, 2011.

[13] H. Pawlik and A. Prociak, "Influence of palm oil-based polyol on the properties of flexible polyurethane foams," Journal of Polymers and the Environment, vol. 20, no. 2, pp. 438-445, 2012. 
[14] Z. S. Petrović, A. Guo, I. Javni, I. Cvetković, and D. P. Hong, "Polyurethane networks from polyols obtained by hydroformylation of soybean oil," Polymer International, vol. 57, no. 2, pp. 275-281, 2008.

[15] Z. S. Petrović, I. Cvetković, D. P. Hong et al., "Vegetable oilbased triols from hydroformylated fatty acids and polyurethane elastomers," European Journal of Lipid Science and Technology, vol. 112, no. 1, pp. 97-102, 2010.

[16] L. Hojabri, X. Kong, and S. S. Narine, "Fatty acid-derived diisocyanate and biobased polyurethane produced from vegetable oil: synthesis, polymerization, and characterization," Biomacromolecules, vol. 10, no. 4, pp. 884-891, 2009.

[17] L. Hojabri, X. Kong, and S. S. Narine, "Novel long chain unsaturated diisocyanate from fatty acid: synthesis, characterization, and application in bio-based polyurethane," Journal of Polymer Science, Part A: Polymer Chemistry, vol. 48, no. 15, pp. 33023310, 2010.

[18] A. Campanella, L. M. Bonnaillie, and R. P. Wool, "Polyurethane foams from soyoil-based polyols," Journal of Applied Polymer Science, vol. 112, no. 4, pp. 2567-2578, 2009.

[19] R. Tanaka, S. Hirose, and H. Hatakeyama, "Preparation and characterization of polyurethane foams using a palm oil-based polyol," Bioresource Technology, vol. 99, no. 9, pp. 3810-3816, 2008.

[20] U. Stirna, U. Cabulis, and I. Beverte, "Water-blown polyisocyanurate foams from vegetable oil polyols," Journal of Cellular Plastics, vol. 44, no. 2, pp. 139-160, 2008.

[21] M. A. Mosiewicki, U. Casado, N. E. Marcovich, and M. I. Aranguren, "Polyurethanes from tung oil: polymer characterization and composites," Polymer Engineering \& Science, vol. 49, no. 4, pp. 685-692, 2009.

[22] I. O. Bakare, C. Pavithran, F. E. Okieimen, and C. K. S. Pillai, "Synthesis and characterization of rubber-seed-oil-based polyurethanes," Journal of Applied Polymer Science, vol. 109, no. 5, pp. 3292-3301, 2008.

[23] ASTM International, "American society for testing materials, standard test methods for testing polyurethane raw materials: determination of hydroxyl numbers of polyols," ASTM (D427411), ASTM International, West Conshohocken, Pa, USA, 2011.

[24] ASTM International, "American Society for testing materials, standard test methods for polyurethane raw materials: determination of acid and alkalinity numbers of polyols," ASTM (D4662-08), ASTM International, West Conshohocken, Pa, USA, 2008.

[25] ASTM International, "American society for testing materials, standard test method for determination of water in petroleum products, lubricating oils, and additives by coulometric karl fischer titration," ASTM D6304-07, ASTM International, West Conshohocken, Pa, USA, 2007.

[26] ASTM International, "Standard test methods for apparent density of rigid cellular plastics," ASTM D1622-08, American Society for Testing Materials, West Conshohocken, Pa, USA, 2008.

[27] K. Ashida, Polyurethane and Related Foams: Chemistry and Technology, Taylor \& Francis, Boca Raton, Fla, USA, 2007.

[28] S. S. Narine, X. Kong, L. Bouzidi, and P. Sporns, "Physical properties of polyurethanes produced from polyols from seed oils: II. Foams," Journal of the American Oil Chemists' Society, vol. 84, no. 1, pp. 65-72, 2007.

[29] G. Oertel, Polyurethane Handbook: Chemistry-Raw MaterialsProcessing-Application-Properties, Hanser Pubishers, New York, NY, USA, 2nd edition, 1985.
[30] N. Z. K. Shaari, O. T. Lye, and S. Ahmad, "Effect of triethanolamine on the properties of palm-based flexible polyurethane foams," Journal of Oil Palm Research, vol. 16, no. 1, pp. 66-71, 2004.

[31] L. Zhang, X. Ding, and Y. Ou, "Properties of rigid polyurethane foams prepared with synthesized PIPA polyol," American Journal of Chemistry and Application, vol. 1, no. 1, pp. 7-14, 2014.

[32] M. C. Hawkins, B. O’Toole, and D. Jackovich, "Cell morphology and mechanical properties of rigid polyurethane foam," Journal of Cellular Plastics, vol. 41, no. 3, pp. 267-285, 2005.

[33] J. W. Kang, J. M. Kim, M. S. Kim, Y. H. Kim, and W. N. Kim, "Effects of nucleating agents on the morphological, mechanical and thermal insulating properties of rigid polyurethane foams," Macromolecular Research, vol. 17, no. 11, pp. 856-862, 2009.

[34] D. Eaves, Handbook of Polymer Foams, Rapra Technology, Billingham, UK, 2004.

[35] F. Saint-Michel, L. Chazeau, J.-Y. Cavaillé, and E. Chabert, "Mechanical properties of high density polyurethane foams: I. Effect of the density," Composites Science and Technology, vol. 66, no. 15, pp. 2709-2718, 2006.

[36] ASTM International, "Standard test methods for compressive properties of rigid cellular plastics," ASTM D1621-04a, American Society for Testing Materials, West Conshohocken, Pa, USA, 2004.

[37] A. Palanisamy, M. S. L. Karuna, T. Satyavani, and D. B. Rohini Kumar, "Development and characterization of waterblown polyurethane foams from diethanolamides of karanja oil," Journal of the American Oil Chemists' Society, vol. 88, no. 4, pp. 541-549, 2011.

[38] M. S. Han, S. J. Choi, J. M. Kim et al., "Effects of silicone surfactant on the cell size and thermal conductivity of rigid polyurethane foams by environmentally friendly blowing agents," Macromolecular Research, vol. 17, no. 1, pp. 44-50, 2009. 

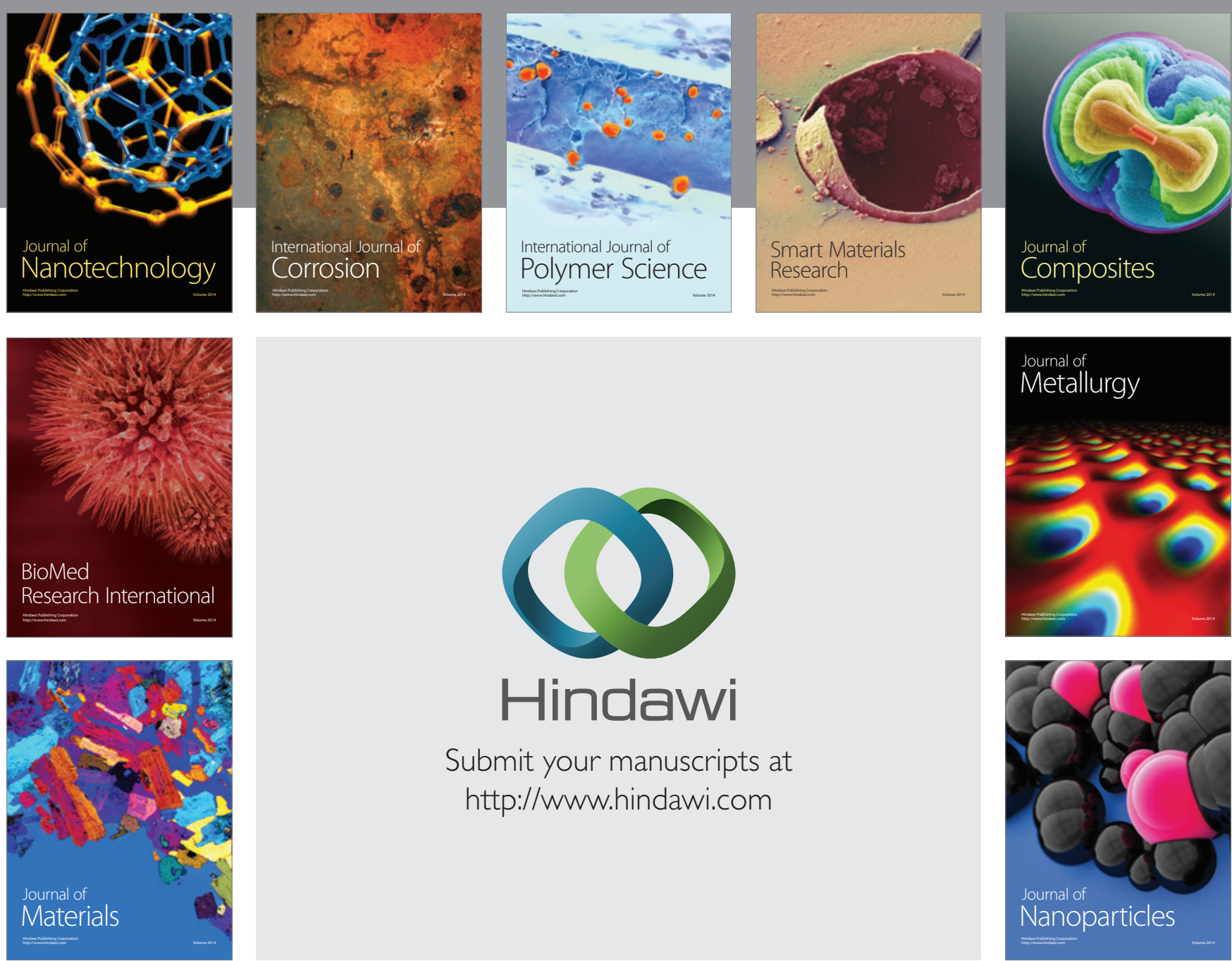

\section{Hindawi}

Submit your manuscripts at

http://www.hindawi.com

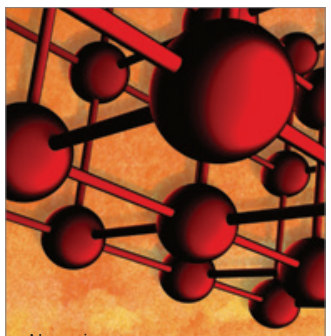

Materials Science and Engineering
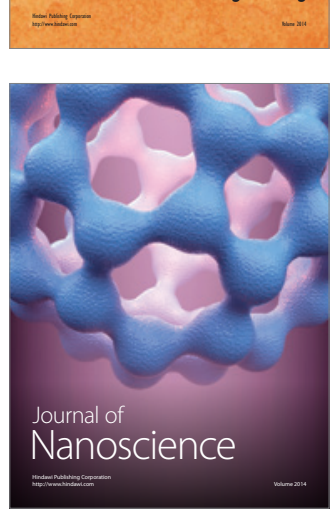
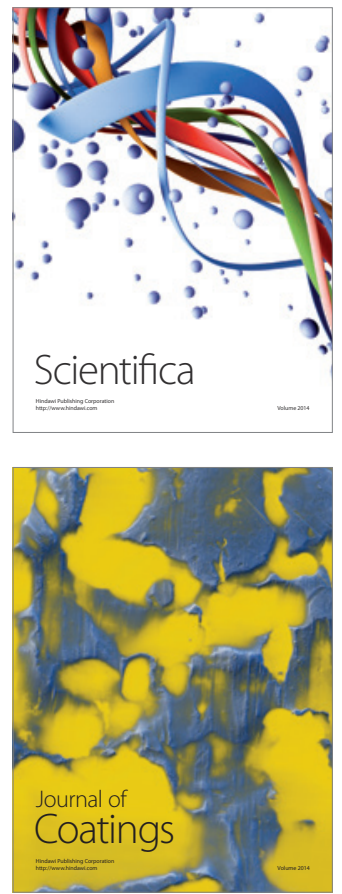
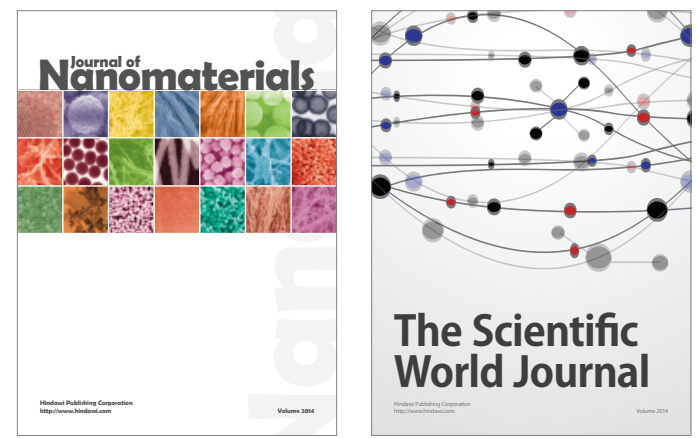

The Scientific World Journal
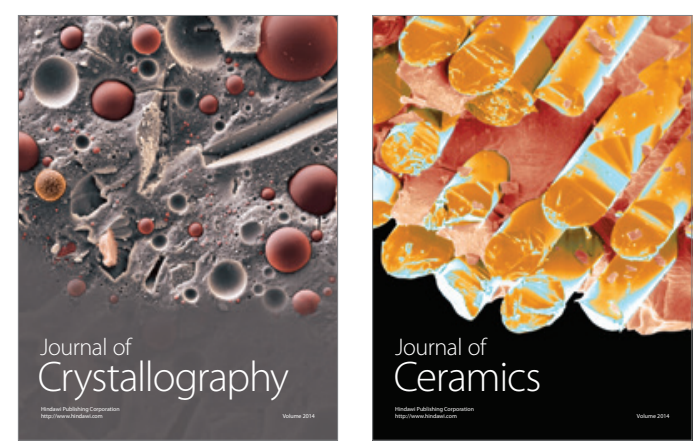
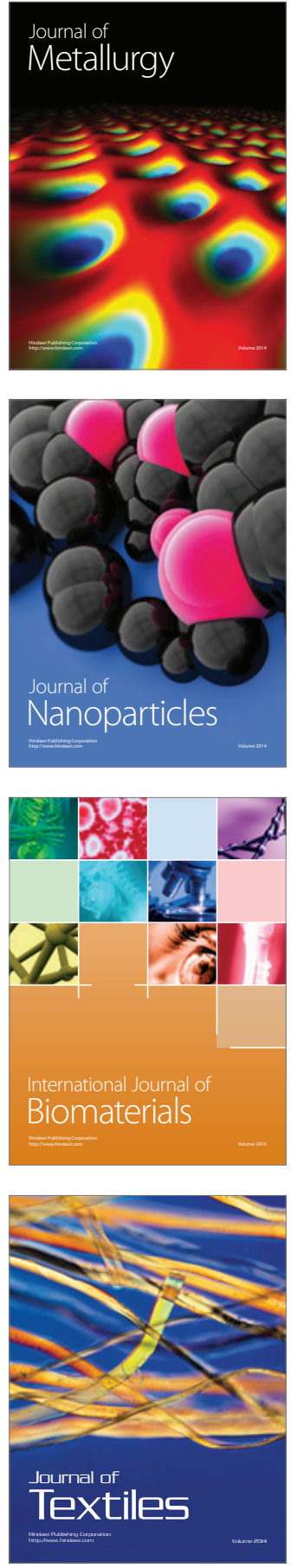